\title{
Rice price shocks and household welfare in Papua New Guinea
}

\author{
Emily Schmidt, Paul Dorosh, and Rachel Gilbert
}

Rice prices in international markets rose sharply between December 2019 and May 2020, increasing, for example, by 25 percent in Thailand and 30 percent in Vietnam. Given that essentially all of the rice supply for Papua New Guinea (PNG) comes from rice imports, the domestic price of rice in PNG is likely to rise substantially in coming months. Although PNG's food economy is dominated by domestically produced starchy staples, rice imports have almost doubled from 167,000 tons annually in 2005 to an estimated 300,000 tons in 2020.

This note examines rice consumption patterns and international trade trends for PNG to shed light on the potential impacts in rural and urban PNG of disruptions to rice imports. Our model simulations indicate that a 30 percent rise in the world price of rice would be expected to decrease the rice consumption of poor households by 17.3 percent. Under this scenario, consumers in poor households, which are those in the bottom 40 percent of the household expenditure distribution in PNG, would suffer a net welfare loss of USD 23.0 million, equivalent to a 1.6 percent decrease in a per capita daily income of one US dollar.

\section{Household rice consumption in PNG}

Pairing data from the 2009-10 Household Income Expenditure Survey (HIES) for PNG with more recently collected household
Key Policy Messages

- An international rice price shock will have significant effects on the welfare of rice consumers in PNG.

- Model simulations indicate that a 30 percent rise in the world price of rice would reduce total rice consumption in PNG by between 16.8 and 18.9 percent and reduce rice consumption of the poor by 17.3 percent.

- Poor households in the Autonomous Region of Bougainville dedicate 22 percent of their total food budget to rice. A 30 percent increase in the rice price would decrease rice consumption in poor households there by 16.3 percent from 47 to 39 kgs/person/year.

- Supporting and enabling local and regional fresh food markets to function as smoothly as possible will be crucial to ensuring food availability in rural and urban areas in both the short and long term.

- Assuming a protracted COVID-19 pandemic, a targeted cash transfer could be an option to offset the negative impacts of a rice price shock, as well as other indirect shocks. 
consumption expenditure data from IFPRI's Rural Household Survey on Food Systems of 2018, we construct a simple model of PNG's rice economy. The most recent nationally representative survey for PNG is the 2009/10 HIES, which surveyed 4,191 households and provides detailed regional-level information of consumption for rural, urban, and metro populations. According to the 2009/10 HIES data, annual rice consumption was 195,500 tons, or only 1.2 percent higher than average annual imports in 2009 and 2010. Almost 30 percent of rice in PNG was consumed in urban areas where per capita consumption was nearly 2.5 times that of rural areas $59 \mathrm{~kg} /$ capita versus $24 \mathrm{~kg} /$ capita, respectively. Non-poor households consumed $40 \mathrm{~kg} / \mathrm{capita}$ of rice, 2.7 times more than poor households (15 kg/capita).

Given that the 2009/10 HIES data provide a snapshot of rice consumption patterns from a decade ago, we use the IFPRI Rural Survey on Food Systems in PNG (RSFS), implemented in 2018, to estimate household rice consumption in $2020 .{ }^{1}$ For rural households in Momase region, which make up three-quarters of RSFS sample households, estimates are based on the RSFS data. Rice consumption in other regions is estimated using shares of total national rice consumption in the non-Momase regions from the 2009/10 HIES.

Rice consumption in the RSFS sample households echo the consumption patterns seen in the 2009/10 HIES data. Riceconsuming households with higher incomes, as approximated by total expenditures, consume greater quantities of rice per capita (Figure 1). Although the quantity of rice consumed diverges between poor and nonpoor households, the share of household total expenditures that is dedicated to rice is similar at 6.8 and 6.0 percent, respectively, between poor and non-poor households.
Figure 1: Scatter-plot of daily per capita rice consumption by total daily expenditure for 2018 RSFS survey households

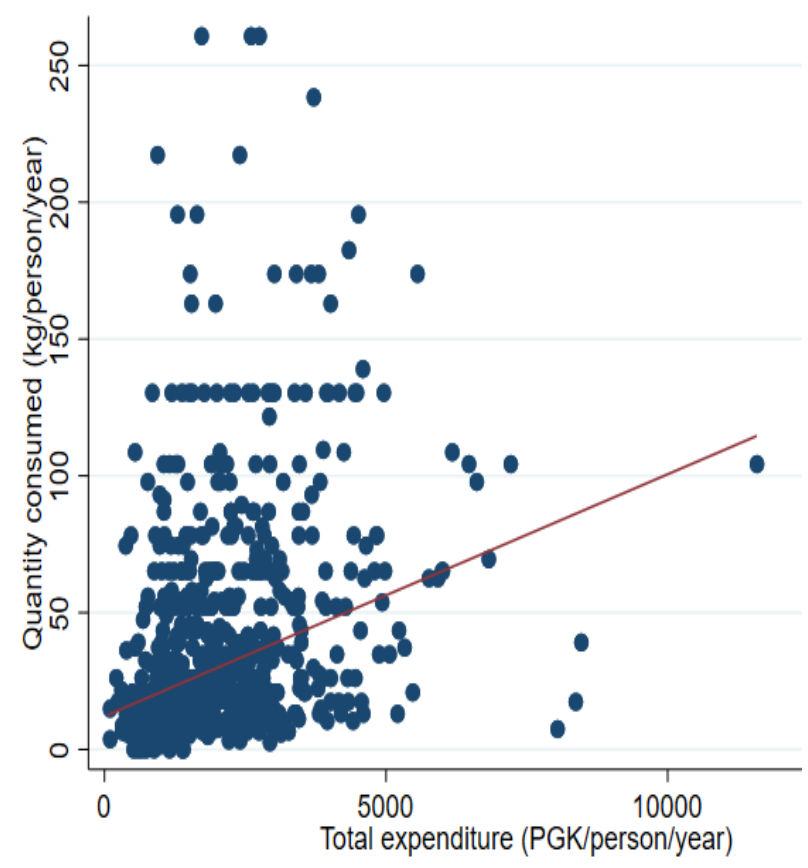

Source: Authors' calculations using data from the IFPRI Rural Survey on Food Systems (RSFS), 2018

Comparatively, across PNG almost half of the household food budget on average is comprised of starches, predominantly roots, tubers, and bananas. The second largest share of household expenditure is spent on meat, fish and eggs in both poor and non-poor households at 10.8 and 13.0 percent, respectively. Rice makes up a smaller share of overall household food budgets. However, regional differences exist. For example, poor households in the Autonomous Region of Bougainville (ARoB) dedicate almost 22 percent of their total food budget to rice.

\section{Effects of world rice price changes on rice consumption and household welfare in PNG}

As shown in Figure 2, rice prices increased in world markets in 2020. Between December 2019 and April 2020, the export price (free-onboard) of Bangkok A1 Super rice rose by more than 25 percent and that of Vietnam $5 \%$ broken rice rose by 30 percent. In contrast to

\footnotetext{
1 The 2018 IFPRI Rural Survey on Food Systems focused on four specific rural, lowland areas of PNG and was not designed to provide representativeness at any administrative level nor to evaluate urban estimates of rice consumption. See:

Schmidt, E., R. Gilbert, B. Holtemeyer, G. Rosenbach, and T. Benson. 2019. Papua New Guinea Survey Report: Rural Household Survey on Food Systems. IFPRI Discussion Paper 01801. Washington, DC: International Food Policy Research Institute (IFPRI).
} 
Table 1: Estimated distribution of rice consumption in Papua New Guinea, 2020

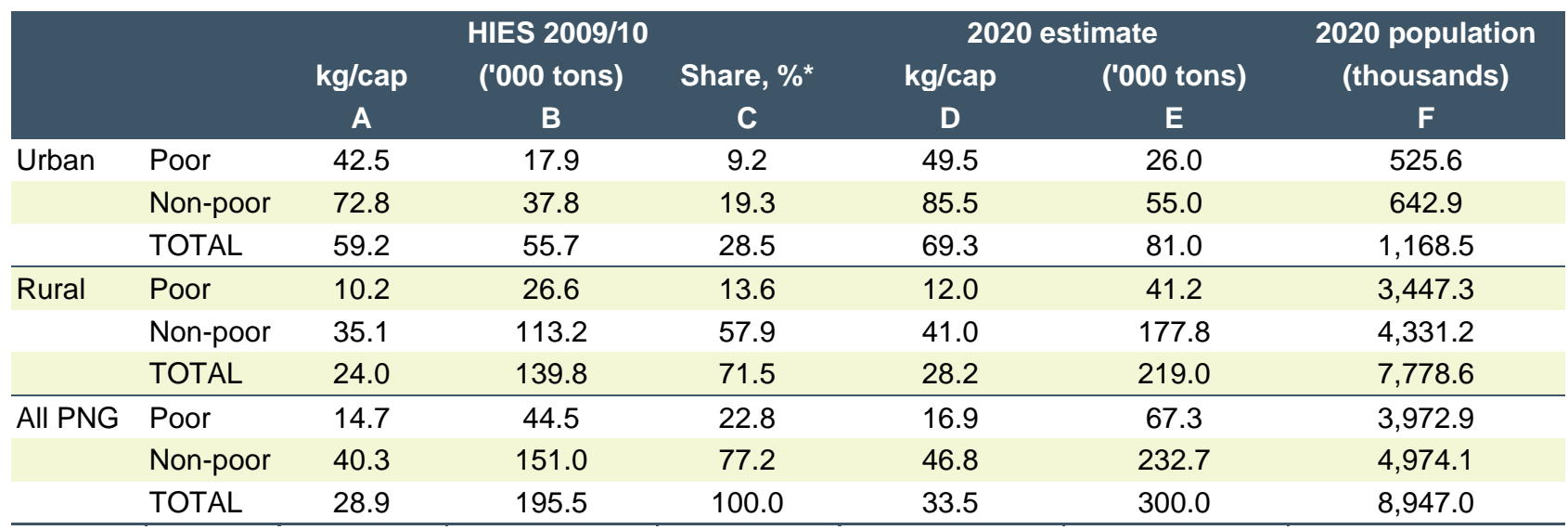

Source: Authors' calculations using HIES 2009-10 and IFPRI PNG-RSFS (2018)

Notes: * Share of total PNG consumption. The poor are households in the bottom 40 percent of the per capita expenditure distribution.

these movements in rice prices, wheat prices did not fluctuate greatly during the COVID-19 pandemic to date. ${ }^{2}$

Figure 2: International export prices of rice and wheat, Jan. 2017 to Apr. 2020

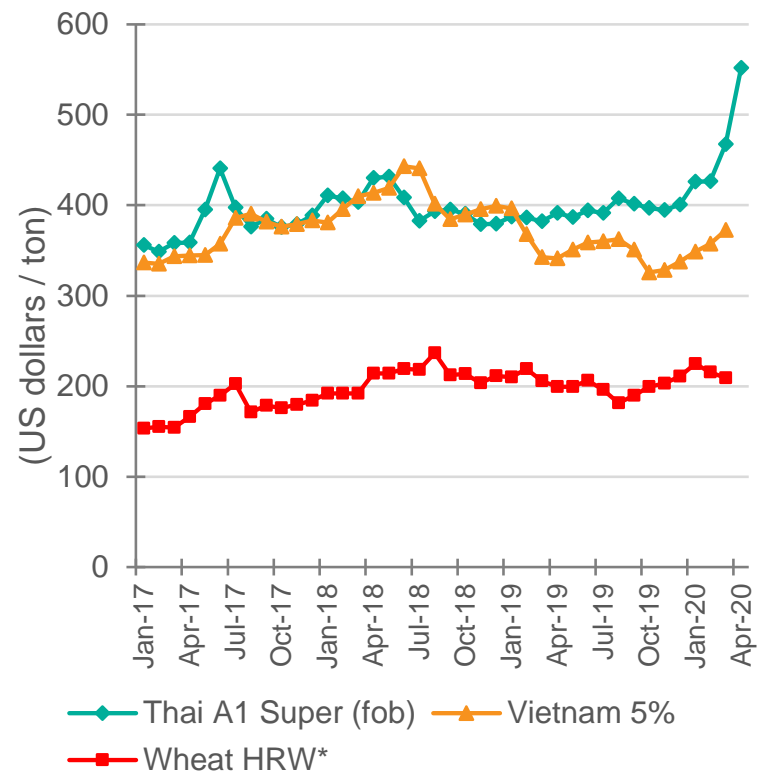

Source: Authors' calculations using World Bank (2020) and USDA (2020) data.

Note: Thai A1 Super (fob.) = rice, Thailand, 100\% broken, gov't standard, free-on-board (f.o.b.) Bangkok.

Vietnam $5 \%$ = rice, Vietnam, $5 \%$ broken, milled, minimum export price, f.o.b. Hanoi;

Wheat HRW = hard red winter wheat, no. 1, ordinary protein, export price at US Gulf port for 30 day shipment.
Table 1 provides a description of how rice consumption is estimated for urban and rural areas of PNG in 2020. We utilize the estimated total population for 2020 and per capita rice consumption data from the RSFS survey to update the rice consumption estimates from the 2009/10 HIES for rural and urban areas (Column D and E). Assuming an estimated 300,000 tons total rice consumption in 2020 , average per capita rice consumption in PNG is estimated at $33.5 \mathrm{~kg} /$ capita - 69.3 $\mathrm{kg} /$ capita in urban areas and $28.2 \mathrm{~kg} /$ capita in rural areas.

Table 2 presents the simulation results of a 30 and a 50 percent increase in the world price of rice (Simulations 1 and 3, respectively). In Simulations 2 and 4, respectively, we model the same price increases, but also include a 10 percent negative income shock. The 10 percent income shock reflects a potential slowdown in the PNG economy due to COVID-19 restrictions on movement of people and goods. The percentage changes in rice consumption for each household are calculated as the household's price elasticity of demand for rice times the percentage change in the rice price. ${ }^{3}$

\footnotetext{
${ }^{2}$ International wheat prices (hard red winter) were essentially unchanged, falling by only 0.9 percent. https://www.worldbank.org/en/research/commodity-markets.

${ }^{3}$ The elasticities of demand for rice are derived from employing a Heckman two-stage model to estimate the marginal effect of income on rice consumption. The coefficient $\beta$ of 1.615 on the logarithm of household-level unit rice price in the Heckman second-stage regression implies an overall own-price elasticity of -0.744 (equal to $\beta$ divided by the average rice budget share of consumers of 6.3
} 
Table 2: Effects of increases in the world price of rice: PNG model simulation results

\begin{tabular}{|c|c|c|c|c|c|}
\hline & Base & Simulation 1 & Simulation 2 & Simulation 3 & Simulation 4 \\
\hline \multicolumn{6}{|l|}{ Simulation scenario components: } \\
\hline World rice price increase (\%) & & 30.0 & 30.0 & 50.0 & 50.0 \\
\hline Household income shock (\%) & & 0.0 & -10.0 & 0.0 & -10.0 \\
\hline Domestic rice production ('000 tons) & 0.6 & 0.6 & 0.6 & 0.6 & 0.6 \\
\hline Rice imports ('000 tons) & 300.0 & 249.6 & 243.2 & 225.6 & 219.8 \\
\hline Total supply (Demand) ('000 tons) & 300.6 & 250.2 & 243.8 & 226.2 & 220.4 \\
\hline Total demand (\% change) & --- & -16.8 & -18.9 & -24.7 & -26.7 \\
\hline Import price (CIF, USD/ton) & 849.6 & 1104.4 & 1104.4 & 1274.3 & 1274.3 \\
\hline Value of rice imports (million USD) & 254.9 & 271.9 & 265.0 & 281.8 & 274.6 \\
\hline Rice retail price (Kina/kg) & 4.53 & 5.81 & 5.81 & 6.67 & 6.67 \\
\hline Retail price change (\%) & --- & 28.2 & 28.2 & 47.1 & 47.1 \\
\hline \multicolumn{6}{|c|}{ Net benefits for poor households, (million USD) } \\
\hline Metro & --- & -3.70 & -3.65 & -5.90 & -5.81 \\
\hline Other Urban & --- & -5.20 & -5.12 & -8.28 & -8.16 \\
\hline Rural Lowlands - Mainland & --- & -5.76 & -5.68 & -9.18 & -9.05 \\
\hline Rural Highlands - Mainland & --- & -4.32 & -4.26 & -6.88 & -6.79 \\
\hline Rural Islands & --- & -4.00 & -3.94 & -6.37 & -6.28 \\
\hline Total Poor & -- & -22.99 & -22.66 & -36.61 & -36.10 \\
\hline USD/capita, poor households & --- & -5.79 & -5.70 & -9.21 & -9.08 \\
\hline Share of USD $1.00 /$ day income, $\%$ & --- & -1.6 & -1.6 & -2.5 & -2.5 \\
\hline
\end{tabular}

Source: Model simulations.

Notes: Own-price elasticities of demand (poor: -0.68 , non-poor: -0.79 ); income elasticities of demand (poor: 0.08, non-poor: 0.39 ). $\mathrm{CIF}=$ price includes cost, insurance, and freight.

Figure 3: Net losses for the poor with a $30 \%$ rice price increase (Simulation 1 ) and with a $30 \%$ rice price increase $\& 10 \%$ income decrease (Simulation 2)

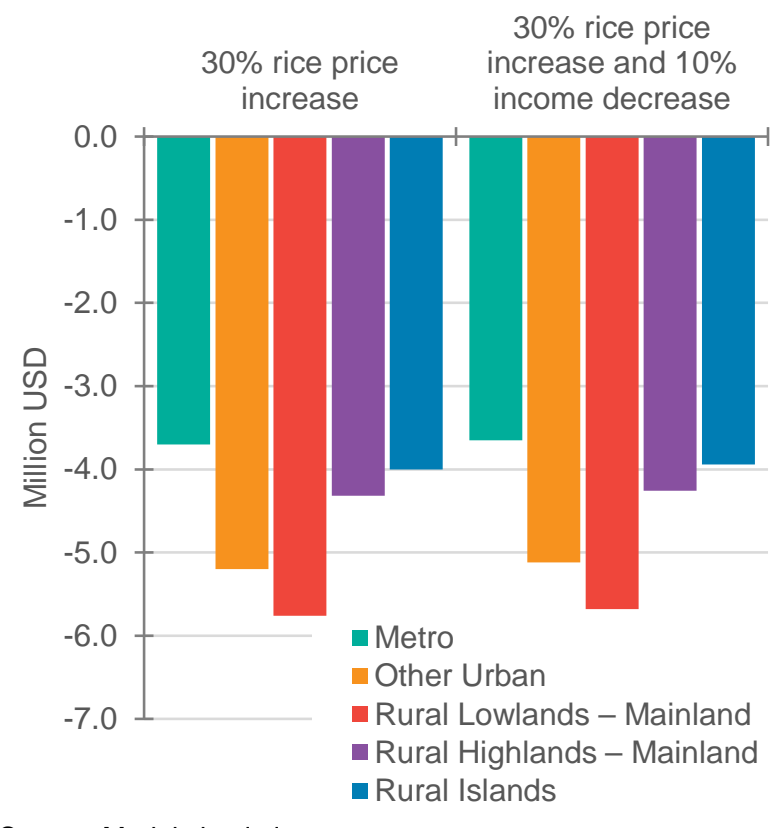

Turning to our model simulation results, a 30 percent rice price increase with no household income shock (Table 2, Simulation 1) results in a 16.8 percent decline in demand for rice and an increase in the rice import bill from USD 254.9 million to USD 271.9 million. The household groups with the largest rice consumption, those in the Rural Lowlands of Southern and Momase regions and those in the Other Urban areas, which comprise the urban areas of all regions, except for Port Moresby and Lae, suffer losses of USD 5.8 million and USD 5.2 million, respectively (Figure 3).

A 30 percent rice price increase that also includes a 10 percent negative income shock, reflecting a potential slowdown in the PNG economy (Table 2, Simulation 2), suggests that rice consumption falls by 18.9 percent (a 2.1 percentage point greater fall than for Simulation 1). The welfare loss for poor

percent minus one). In the simulations discussed here, we use the $\beta$ coefficient of 1.615 and the mean budgets shares ( $W$ ) of poor and non-poor households, respectively, to calculate own-price elasticities of -0.761 and -0.730 for the poor and non-poor, respectively. We use the coefficient on the logarithm of total expenditures $\beta_{Y}(-4.640)$ calculated in the Heckman second-stage regression to calculate expenditure elasticities $\left(=1+\beta_{Y} / \mathrm{w}\right)$ of 0.314 and 0.225 , for the poor and non-poor, respectively. 
households due to the price change is slightly smaller (USD 22.7 million) than in

Simulation 1 because of the downward shift in demand, i.e., lower rice consumption, caused by the income shock (Figure 3 ).

A greater world rice price shock of 50 percent (Table 2, Simulation 3), reflecting possible further restrictions on trade by major rice exporters, results in correspondingly greater declines in rice consumption and welfare of the poor. Consumption of rice by the average poor household in the 2018 rural RSFS sample would fall by about 16 percent, though the impact on households differs greatly across regions. Coupling the 50 percent world rice price shock with a 10 percent drop in income (Table 2, Simulation 4) results in somewhat lower welfare losses for the poor because their now lower income restricts their consumption of rice so they substitute lower price food types for rice.

The share of rice in food expenditures of the poor ranges from only 7.6 percent in the Middle Ramu area of East Sepik in Madang province to 22.2 percent in Bougainville (ARoB) (Figure 4). Given the greater expenditure share dedicated to rice in poor households in $A R o B$, a 30 percent increase in rice prices will decrease rice consumption by

Figure 4: Rice quantity consumed per capita per year and food expenditure share for rice in East Sepik and Bougainville

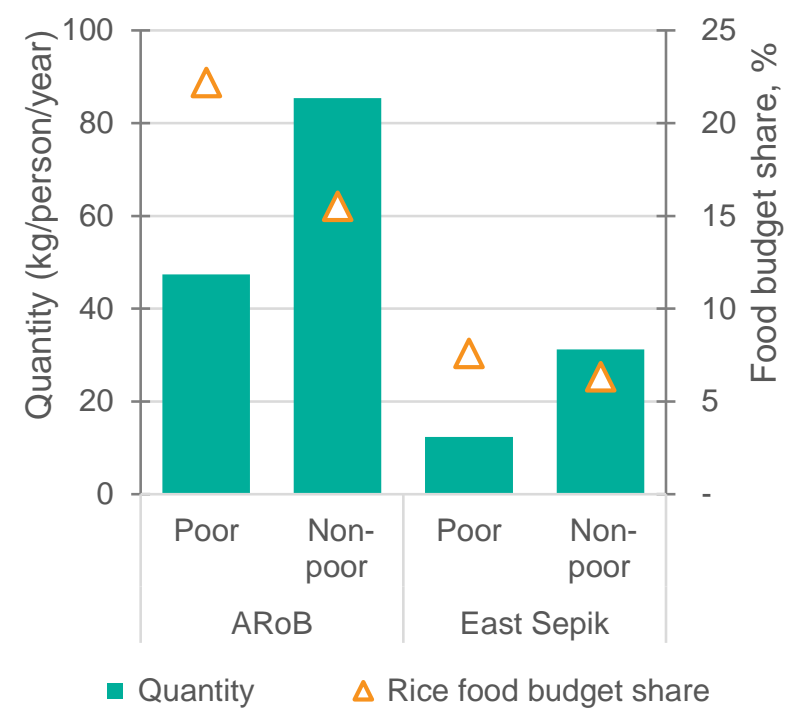

Source: Authors' calculations using IFPRI - RSFS (2018). Note: $A R o B=$ Autonomous Region of Bougainville.
16.3 percent or by about $8 \mathrm{~kg} /$ person/year, i.e., from approximately $47.3 \mathrm{~kg} /$ person/year to $39.6 \mathrm{~kg} /$ person/year. Even for non-poor households in $\mathrm{ARoB}$, rice comprises over 15 percent of the overall food budget.

Comparatively, in East Sepik, due to lower rice consumption among households under normal circumstances, a 30 percent increase in rice prices would only reduce average rice consumption for poor households by approximately $2 \mathrm{~kg} /$ person/year.

Non-poor households in the RSFS sample consumed about twice as much rice as poor households on a per capita basis - 34.2 versus $16.6 \mathrm{~kg} / \mathrm{capita}$. However, less of their overall food budget share is dedicated to rice purchases (Figure 4). Given a 30 percent price increase, the average rice consumption for the non-poor would fall by an average of 19 percent.

\section{Conclusions}

Rice is not the major staple crop in PNG. However, on average, it still accounts for 14 percent of total calories and about 6 percent of total expenditures (including the value of own consumption of other goods) for households in the 2018 IFPRI rural household survey.

Model simulations indicate that a 30 percent rise in the world price of rice, which is approximately equal to the actual increase in world rice prices in early-2020, can be expected to decrease overall rice consumption in PNG by between 16.8 and 18.9 percent and reduce the rice consumption of the poor by 17.3 percent. Including the effects of a potential 10 percent decrease in their household incomes because of a possible COVID-19 related economic slowdown, rice consumption of the poor falls overall by 19.9 percent. Because domestic rice production in PNG constitutes on 0.2 percent of supply, changes in production have little effect on imports or incomes. Overall, the welfare loss to poor households is about USD 23 million. 
Apart from major outbreaks of COVID-19 within the country, PNG households are still susceptible to the effects of the pandemic. If supply chains of locally produced foods are disrupted, the effects of the world rice price increase would be magnified, as nonagricultural producing households would not be able to readily switch some of their consumption of rice to consumption of local roots and tubers, such as sweet potato, yam, or taro.

Public health measures involving restrictions of movement of people may be needed in some cases, but it is important to avoid domestic market disruptions when possible. This is crucial for both farmers of domestically produced crops, who engage in the cash economy to supplement their food consumption, i.e., purchases of tinned fish, etc., and for consumers, who count on local food markets for fresh produce and staple food items. Small surveys of wholesale traders and regular monitoring of prices of rice and other food commodities, which is not now being done in PNG, could provide valuable information on current and potential domestic food supply problems.

Increased rice imports are one means of increasing food supply in PNG in the event of major world price spikes in the future. But unless government imports were distributed in such a way as to increase total demand for rice, such as by targeting poor households who otherwise may have consumed very little rice, government imports would likely displace private sector imports, so the net effect on supply could be small. A targeted cash transfer could be a better option, not only to offset the negative impacts of a rice price shock, but other potential shocks, as well.

\section{ABOUT THE AUTHORS}

Emily Schmidt is a Research Fellow in the Development Strategy and Governance Division (DSGD) of the International Food Policy Research Institute (IFPRI), based in Madrid, Spain. Paul Dorosh is a Senior Research Fellow and Division Director in DSGD of IFPRI, based in Washington, DC. Rachel Gilbert is a Research Analyst in DSGD of IFPRI, based in Washington, DC.

\section{ACKNOWLEDGMENTS}

We thank the Department of Foreign Affairs and Trade of the government of Australia and the CGIAR Research Program on Policies, Institutions, and Markets for funding and facilitating the work undertaken to produce this note. We also acknowledge comments and suggestions received from the Australia High Commission in Port Moresby to improve it.

\section{INTERNATIONAL FOOD POLICY RESEARCH INSTITUTE A world free of hunger and malnutrition}

